\title{
DISEASE REACTION OF POTATO GERMPLASMS AND TRUE POTATO SEEDS AGAINST RHIZOCTONIA SOLANI KUHN
}

\author{
Md Maniruzzaman Khandaker, Abul Khair ${ }^{1}$ and Md Khurshed Alam Bhuiyan ${ }^{2}$ \\ Department of Botany, Jagannath University, Dhaka, Bangladesh
}

Key words: Germplasm, Potato, TPS, Rhizoctonia solani

\begin{abstract}
Screening of 25 potato germplasms against Rhizoctonia solani BTB115 in artificially infested field condition were carried out. No germplasm was found resistant to $R$. solani. Only six germplasms appeared to be moderately resistant. Cardinal, Diamant and Heera were found as highly susceptible varieties. True potato seed BARI TPS1 was tested against two virulent isolates of $R$. solani DK64 and BTB115. Only 21\% and 29\% resistant seedlings against the DK64 and BTB115 isolates, respectively were obtained compared to $85 \%$ seedlings in control.
\end{abstract}

Susceptibility of potato to 55 diseases has been recorded in Bangladesh (Ali and Dey 1994). Stem canker and black scurf caused by Rhizoctonia solani Kuhn is one of the most destructive diseases of potato. The incidence of three diseases in Bangladesh is $8.40 \%$ (Khandaker et al. 2006). Loss caused by $R$. solani were estimated to 5-15\% world-wide (Stachiwicz et al. 1978). The fungus is an unspecialized parasite, survive in soil in the absence of host plant and make itself a very difficult pathogen to manage.

Cultivation of resistant varieties is the most economic and environmentally safe method of crop disease management. But availability of resistant genotypes is reported to be very limited. Mikheeva (1988) evaluated some potato varieties for field resistant to $R$. solani and found that the Norland variety was most susceptible at a high inoculum concentration but Erfolg variety showed almost no infection of the roots and tubers. Pietkiewicz and Chorozewski (1983) studied with 44 varieties of potato and found that seven varieties were resistant to $R$. solani and three varieties viz., Odra, Poprad and Reda were highly resistant.

The present experiment was undertaken to investigate the resistance level of the recommended varieties and lines as well as true potato seeds against $R$. solani.

To evaluate the disease responses of potato germplasms against virulent isolate of $R$. solani, 25 germplasms such as Adora, Arinda, Cardinal, Dheera, Diamant, Heera, Kuroda, Multa, Prelude, Raja, Patronies, 44, 37, 140, 430, 93.314, 93.316, 93.319, 87.12, 88.163, 94.42, 94.66, 384011.3, 384091.11 and 384558.10 were tested. Inocula of the fungal isolates were prepared following Bandy et al. (1984). Fifteen mycelial agar discs of $R$. solani isolate BTB115 were transferred into conical flasks and were mixed with autoclaved wheat grains. The flasks were incubated at $25 \pm 2^{\circ} \mathrm{C}$ for three weeks. After incubation the colonized wheat grains were air dried and stored at $4^{\circ} \mathrm{C}$ until use. Before sowing, the land was sterilized with $1 \%$ formaldehyde. Ten days later the soil of the field was inoculated with the pathogen R. solani isolate @94 g/m² (Yuen et al. 1994). Plot size was $0.60 \mathrm{~m} \times 1 \mathrm{~m}$ and each plot was divided longitudinally into two rows with $0.1 \mathrm{~m}$ gap. In each row 5 potato seeds were sown after seven days of inoculation with isolates. Each seed tuber was cut longitudinally into two halves and air dried $24 \mathrm{~h}$ before planting.

\footnotetext{
${ }^{1}$ Department of Botany, Jahangirnagar University, Savar, Dhaka, Bangladesh. ${ }^{2}$ Department of Plant Pathology, Bangabandhu Sheikh Mujibur Rahman Agricultural University, Gazipur, Bangladesh.
} 
Recommended doses of well decomposed cowdung as well as urea, triple super phosphate and muriate of potash for N, P and K, respectively were used. Design of the experiment was RCB having three replications. Data on total number of plants and tubers, infected number of plants and tubers, ratings of percent disease index (PDI) and yield of each plot were recorded. Disease incidences were calculated with the following formula:

$$
\text { Disease incidence }=\frac{\text { Number of infected plants }}{\text { Total number of potato plants }} \times 100
$$

The PDI was appraised by indexing the visible damage of a given plant on a six degree rating scale from 0 (no disease symptom) to 5 (plant completely girdled/ more than $80 \%$ or whole of the tuber infected which may be cracked and deformed) (Sneh et al. 1966, Balali et al. 1995). The PDI was calculated with the following formula:

$$
\text { PDI }=\frac{\text { Summation of all ratings }}{\text { Number of plants/tubers observed } \times \text { maximum rating (5) }} \times 100
$$

Responses of true potato seeds BARI TPS1 were assessed against $R$. solani BTB115 and DK64. Steam sterilized soil was inoculated with the isolates @ 10g inocula in per kg of soil separately. Then inoculated soil was poured in plastic trays and incubated for seven days. Steam sterilized soil without inoculation with $R$. solani isolate served as control. One hundred seeds were sown in each tray having three replications for each treatment. Data on seedling emergence and seedling survival were recorded 20, 30 and 40 days after seed sowing.

None of the germplasms showed disease free tubers against $R$. solani although its severity varied considerably (Table 1). The highest disease incidence of potato was observed in Cardinal and it was followed by Diamant and Heera. About 53\% disease incidence was observed in 88.163, Adora and Kuroda. The lowest incidence was found in Raja. The highest PDI was recorded in Diamant. The lowest PDI was observed in 94.42 (Table 1). The highest yield was recorded in variety Raja and the lowest yield was in germplasm 140. Yield is an important character of a variety. The variation on yield might be genetic and inherent character of concern variety, which might be affected by the disease severity (Table 1).

Table 1. Response of potato germplasms against $R$. solani BTB115.

\begin{tabular}{llll}
\hline Germplasm & $\begin{array}{c}\text { Disease incidence } \\
(\%)\end{array}$ & \multicolumn{1}{c}{ PDI } & $\begin{array}{c}\text { Yield/ha } \\
(\mathrm{t})\end{array}$ \\
\hline Adora & $53.33(7.30) \mathrm{a}-\mathrm{f}$ & $25.57(5.06) \mathrm{a}-\mathrm{g}$ & $14.01 \mathrm{a}-\mathrm{d}$ \\
Arinda & $26.19(5.11) \mathrm{jk}$ & $15.96(3.99) \mathrm{fgh}$ & $11.12 \mathrm{~cd}$ \\
Cardinal & $61.46(7.84) \mathrm{a}$ & $35.15(5.91) \mathrm{ab}$ & $15.33 \mathrm{a}-\mathrm{d}$ \\
Dheera & $42.01(6.47 \mathrm{~d}-\mathrm{h}$ & $23.26(4.80) \mathrm{b}-\mathrm{h}$ & $17.05 \mathrm{ab}$ \\
Diamant & $61.07(7.81) \mathrm{ab}$ & $38.34(6.16) \mathrm{a}$ & $14.19 \mathrm{a}-\mathrm{d}$ \\
Heera & $60.01(7.74) \mathrm{ab}$ & $33.03(5.74) \mathrm{abc}$ & $16.10 \mathrm{abc}$ \\
Kuroda & $53.03(7.25) \mathrm{a}-\mathrm{f}$ & $29.76(5.43) \mathrm{a}-\mathrm{d}$ & $12.62 \mathrm{bcd}$ \\
Multa & $41.02(6.40) \mathrm{e}-\mathrm{h}$ & $22.86(4.76) \mathrm{b}-\mathrm{h}$ & $16.81 \mathrm{ab}$ \\
Prelude & $44.06(6.64) \mathrm{c}-\mathrm{h}$ & $25.60(5.05) \mathrm{a}-\mathrm{g}$ & $11.85 \mathrm{bcd}$ \\
Raja & $21.80(4.66) \mathrm{k}$ & $15.51(3.89) \mathrm{gh}$ & $18.51 \mathrm{a}$ \\
Patronies & $41.82(6.41) \mathrm{e}-\mathrm{h}$ & $23.70(4.80) \mathrm{b}-\mathrm{h}$ & $10.91 \mathrm{~cd}$ \\
44 & $45.27(6.72) \mathrm{b}-\mathrm{g}$ & $23.81(4.85) \mathrm{b}-\mathrm{h}$ & $12.24 \mathrm{~b}-\mathrm{d}$ \\
37 & $49.12(6.96) \mathrm{a}-\mathrm{g}$ & $26.03(5.04) \mathrm{a}-\mathrm{g}$ & $15.40 \mathrm{a}-\mathrm{d}$ \\
\hline
\end{tabular}




\begin{tabular}{llll} 
Contd & & \\
\hline 140 & $49.10(6.99) \mathrm{a}-\mathrm{g}$ & $30.32(5.48) \mathrm{a}-\mathrm{d}$ & $10.07 \mathrm{~d}$ \\
430 & $56.08(7.48) \mathrm{a}-\mathrm{e}$ & $31.19(5.57) \mathrm{a}-\mathrm{d}$ & $11.01 \mathrm{~cd}$ \\
93.314 & $57.26(7.56) \mathrm{a}-\mathrm{d}$ & $28.81(5.17) \mathrm{a}-\mathrm{f}$ & $10.80 \mathrm{~cd}$ \\
93.316 & $49.99(7.04) \mathrm{a}-\mathrm{g}$ & $24.42(4.92) \mathrm{b}-\mathrm{g}$ & $10.31 \mathrm{~d}$ \\
93.319 & $49.59(7.04) \mathrm{a}-\mathrm{g}$ & $29.14(5.39) \mathrm{a}-\mathrm{e}$ & $10.92 \mathrm{~cd}$ \\
87.12 & $50.48(7.08) \mathrm{a}-\mathrm{g}$ & $31.79(5.55) \mathrm{a}-\mathrm{d}$ & $12.15 \mathrm{bcd}$ \\
88.163 & $53.44(7.31) \mathrm{a}-\mathrm{f}$ & $33.33(5.74) \mathrm{abc}$ & $12.11 \mathrm{bcd}$ \\
94.42 & $28.49(5.31) \mathrm{ijk}$ & $14.01(3.74) \mathrm{h}$ & $13.53 \mathrm{a}-\mathrm{d}$ \\
94.66 & $37.20(6.09) \mathrm{g}-\mathrm{j}$ & $17.90(4.22) \mathrm{e}-\mathrm{h}$ & $13.51 \mathrm{a}-\mathrm{d}$ \\
384011.3 & $31.39(5.57) \mathrm{h}-\mathrm{k}$ & $20.18(4.48) \mathrm{d}-\mathrm{h}$ & $14.83 \mathrm{a}-\mathrm{d}$ \\
384091.11 & $38.65(6.20) \mathrm{f}-\mathrm{I}$ & $23.05(4.78) \mathrm{b}-\mathrm{h}$ & $11.10 \mathrm{~cd}$ \\
384558.10 & $43.64(6.58) \mathrm{c}-\mathrm{h}$ & $21.60(4.62) \mathrm{c}-\mathrm{h}$ & $11.00 \mathrm{~cd}$ \\
\hline
\end{tabular}

Figures within parenthesis are square root transformed values. Means in a column having common letter(s) do not differ significantly $(\mathrm{p}=0.05)$ by DMRT

The germplasms were classified according to their disease incidences (Table 2). In Bangladesh, Diamant and Cardinal are very popular varieties cover most of the potato growing areas of the country, but both of them together with Heera were found highly susceptible. Researchers throughout the world tested germplasms to screen against Rhizoctonia disease of potato. Hollins et al. (1983) reported that potato variety King Edward was more resistant than Pentland Brown to isolates of $R$. solani. Asenov (1986) tested 57 varieties and lines of potato against $R$. solani under field and green house conditions, but only four varieties were highly resistant. The reports of above mentioned investigation corroborate the findings of the present experiment.

Table 2. Reaction of 25 potato germplasms against $R$. solani BTB115

\begin{tabular}{lcc}
\hline Germplasm & Number of germplasm & Disease reaction \\
\hline Arinda, Raja, 94.42, 94.66, 384011.3, 384091.11, & 6 & MR \\
Adora, Dheera, Kuroda, Multa, Prelude, Patronies, & 16 & SR \\
$\begin{array}{l}\text { 44, 37, 140, 430, 93.314, 93.316, 93.319, 87.12, } \\
\text { 88.163, 384558.10 }\end{array}$ & & \\
Cardinal, Diamant, Heera & 3 & HS \\
\hline
\end{tabular}

MR = Moderately resistant (20-40\% disease incidence), SR = Slightly resistant (40 - 60\% disease incidence), HS = Highly susceptible (more than $60 \%$ disease incidence).

Response of BARI TPS1 on germination and seedling mortality against $R$. solani was evaluated. Both the isolates of $R$. solani caused severe loss of seedling emergence and mortality was high compared to uninoculated control. Only 21 and 29\% germination of TPS1 seeds were recorded after 20 days of sowing in soil inoculated by DK64.

Under DK64, BTB115 and control about 15, 13 and 83\% seedlings, respectively survived after 30 days and 40 days of sowing (Table 3 ). The study indicated that germination of true potato seeds and survival of seedlings was seriously hampered by $R$. solani, which was in agreement with the findings of Anguiz and Martin (1989). They observed significant differences in seedling survival of true seeds under artificially infested condition by $R$. solani isolates from three different locations and the seedling survival ranged from 22.8 to $44.3 \%$. 
Table 3. Seedling emergence and seedling survival of BARI TPS1 against $R$. solani DK64 and BTB115.

\begin{tabular}{lcccc}
\hline Treatment & $\begin{array}{c}\text { Number of seeds } \\
\text { sowed }\end{array}$ & $\begin{array}{c}\text { Number of seeds } \\
\text { germinated on } \\
\text { 20 days after sowing }\end{array}$ & $\begin{array}{c}\text { Seedling survival on } \\
\text { sowing }\end{array}$ & $\begin{array}{c}40 \text { days after } \\
\text { sowing }\end{array}$ \\
\hline Control & 100 & 85 & 83 & 83 \\
DK64 & 100 & 21 & 15 & 14 \\
BTB115 & 100 & 29 & 13 & 13 \\
\hline
\end{tabular}

\section{References}

Ali MS and TK Dey 1994. Pathological research on tuber crops in Bangladesh. In: Proc. of Workshop on Transf. of CDP crops under Res. Extn. Linkage Progm., held on Oct. 22-27, 1994. BARI, Gazipur, Bangladesh.

Anguiz R and C Martin 1989. Anastomosis groups, pathogenicity and other characteristics of Rhizoctonia solani isolated from potatoes in Peru. Plant Dis. 73: 199-201.

Asenov R 1986. Reaction of potato varieties/lines to Rhizoctonia solani Kuhn. PARZ. 21(3): 109-114.

Balali GR, SM Neate, ES Scott, DL Whisson and TJ Wicks 1995. Anastomosis group and pathogenicity of isolates of Rhizoctonia solani from potato crops in South Australia. Plant Path. 44(6): 1050-1057.

Bandy BP, DH Zinziger and SM Tavantzis 1984. Isolation of anastomosis groups of Rhizoctonia solani from potato field soil in Maine. Phytopath. 74: 1220-1224.

Hollins TW, GJ Jellis and PR Scott 1983. Infection of potato and wheat by isolates of Rhizoctonia solani and Rhizoctonia cerealis. Plant Path. 32(3): 303-310.

Khandaker MM, MKA Bhuiyan and A Khair 2006. Prevalence of stem canker and black scurf disease of potato in Bangladesh. Bangladesh J. Bot. 35(1): 87-90.

Mikheeva LP 1988. Susceptibility of potato varieties to Rhizoctonia under artificial infection. Intensifikatsiya-Kartofelevo-dstvana-severo-zapade. 103-107.

Pietkiewicz J and P Chorozewski 1983. Preliminary assessment of the responses of potato varieties to some tuber skin diseases. Biuletyn-Instytute-Ziemnaiaka 29: 129-139.

Sneh B, J Katan Y Henis and I Wahl 1966. Methods of evaluating inoculum density of Rhizoctonia in naturally infested soil. Phytopath. 56: 74-78.

Stachiwicz H, L Adam and U Albrecht 1978. Possibilities for chemical control of Rhizoctonia solani on potatoes. Nachrichtenblatt-fur-den-Planzenschutz-in-der-DDR 32(10): 208-212.

Yuen GY, MI Craig and LJ Geisler 1994. Biological control of Rhizoctonia solani on tall fescue using fungal antagonists. Plant Dis. 78: 118-123. 